ARTICLE

https://doi.org/10.1038/s41467-019-12770-w

\title{
A domino reaction for generating $\beta$-aryl aldehydes from alkynes by substrate recognition catalysis
}

Weiwei Fang (1D ${ }^{1}$, Felix Bauer ${ }^{1}$, Yaxi Dong ${ }^{1} \&$ Bernhard Breit ${ }^{1 \star}$

The development of universal catalyst systems that enable efficient, selective, and straightforward chemical transformations is of immense scientific importance. Here we develop a domino process comprising three consecutive reaction steps based on the strategy of supramolecular substrate recognition. This approach provides valuable $\beta$-aryl aldehydes from readily accessible $\alpha$-alkynoic acids and arenes under mild reaction conditions, employing a supramolecular Rh catalyst containing an acylguanidine-bearing phosphine ligand. Furthermore, the synthesis of a key intermediate of Avitriptan using this protocol is accomplished. The first step of the reaction sequence is proved to be the regioselective hydroformylation of $\alpha$-alkynoic acids. Remarkably, molecular recognition of the ligand and the substrate via hydrogen bonding plays a key role in this step. Control experiments indicate that the reaction further proceeds via 1,4-addition of an arene nucleophile to the unsaturated aldehyde intermediate and subsequent decarboxylation.

\footnotetext{
${ }^{1}$ Institut für Organische Chemie, Albert-Ludwigs-Universität Freiburg, Freiburg, Germany. *email: bernhard.breit@chemie.uni-freiburg.de
} 
T he pursuit of an ultimate catalytic system, which allows efficient, selective, and straightforward chemical transformations is an area of extreme interest in modern chemical science $^{1}$. In this sense, supramolecular catalysis ${ }^{2,3}$ based on the substrate recognition via specific reversible interactions between substrate and catalyst-mimicking enzymes has emerged as a promising strategy $y^{4-10}$. In a pioneering work by Crabtree et al. ${ }^{11}$, molecular recognition enabled high regioselectivity in the oxygenation of saturated $\mathrm{C}-\mathrm{H}$ bonds. Later, Reek and colleagues $^{12-19}$, Bach and colleagues ${ }^{20-27}$, Zhang and colleagues $^{28-40}$, and our group ${ }^{41-47}$ developed several methodologies resulting in excellent regio- and enantioselectivity, making use of substrate recognition catalysis. Nevertheless, notwithstanding the advances in this field, the scope and applicability of many methodologies $11,12,20,41$ is limited to very specific substrates leading to products with rather low molecular diversity. On the other hand, domino reactions can provide complex molecules in an elegant and efficient way ${ }^{48-52}$. Considering this, we envision that the combination of domino reactivity with supramolecular substrate recognition might overcome this limitation affording complex molecules from different easily available starting materials.

In line with our long-standing research interest in exploring supramolecular concepts in homogeneous catalysis, our group presented several examples of Rh-catalyzed domino reactions enabled by rational-designed supramolecular ligands ${ }^{42,44-47,53}$. In particular, a method for synthesizing terminal aliphatic aldehydes from $\alpha, \beta$-unsaturated carboxylic acids involving a hydroformylation (HF)-decarboxylation sequence was developed (Fig. 1a) ${ }^{42}$. Due to the effect of carboxylic group $(\mathrm{COOH})$, high regioselectivity was achieved. Recently, we successfully reported a
Rh-catalyzed HF-hydrogenation process by using a rationaldesigned supramolecular ligand (L1), which efficiently transformed unsymmetrical $\beta$-alkynoic acids into aliphatic aldehydes in high regio- and chemoselectivity (Fig. 1b) ${ }^{47}$. Mechanistic studies suggested that the key intermediate in this reaction is the unsaturated aldehyde II. In consideration of the success in HF-decarboxylation of $\alpha, \beta$-unsaturated carboxylic acids; herein, we attempt to explore the HF of $\alpha$-alkynoic acids using the supramolecular ligand L1. In this approach, the analog intermediate III is proposed to be generated based on the previous results (Fig. 1c) ${ }^{42,47}$. Then, due to the activation of the carboxyl group, the Michael addition of suitable arenes (such as indole derivatives) to this unsaturated aldehyde III can proceed faster than the competitive hydrogenation of the double bond due to its steric effect. In this way, valuable $\beta$-aryl aldehydes ${ }^{17,54,55}$ are generated after the final decarboxylation step ${ }^{42}$ of the proposed intermediate IV (Fig. 1c).

\section{Results}

Optimization of reaction conditions. To investigate the proposed domino reaction, 2-butynoic acid $\mathbf{S 1}$ and 1,3,5trimethoxybenzene (TMB) were selected as model substrates. The optimization of reaction conditions is shown in Table 1. Initially, the reaction was carried out employing $\mathbf{S 1}$ and TMB $(1: 1, \mathrm{n} / \mathrm{n})$ in 1,2 -dichloroethane (DCE) at $55^{\circ} \mathrm{C}$ in the presence of $1 \mathrm{~mol} \%$ of $\left[\mathrm{Rh}(\mathrm{CO})_{2} \mathrm{acac}\right]$ and $5 \mathrm{~mol} \%$ of $\mathbf{L 1}$ under 6 bar of $\mathrm{CO} / \mathrm{H}_{2}(1: 1)$ (Table 1, entry 1). A nuclear magnetic resonance (NMR) study of the crude reaction mixture indicated that 3-(2,4,6-trimethoxyphenyl)butanal $\mathbf{1}$ was formed as the main product in 35\% yield, similar to the conversion of TMB (36\%, Table 1, entry 1). Despite the full conversion of the starting material S1, no other side

a Previous work

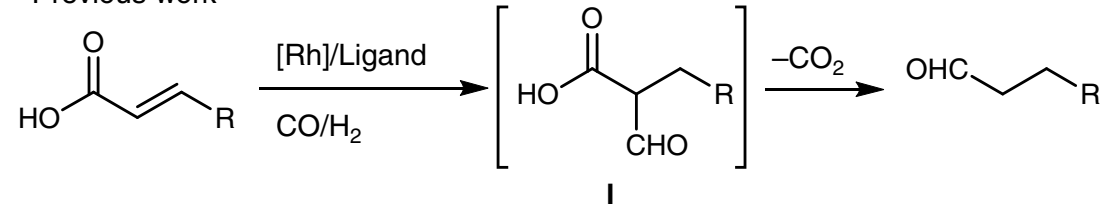

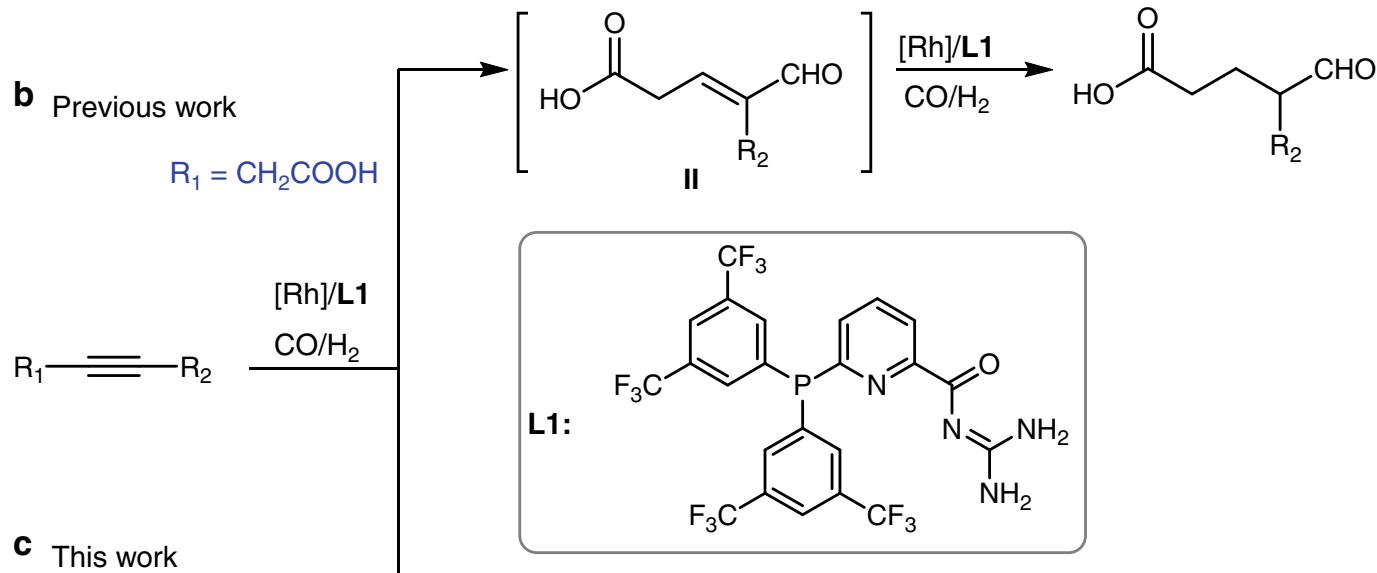

C This work

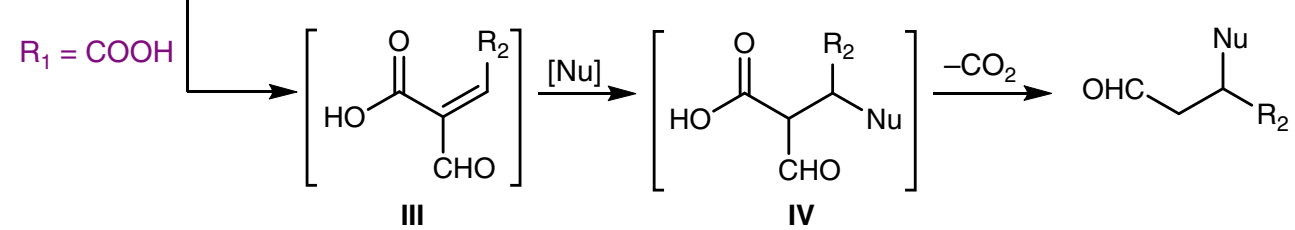

Fig. 1 Domino reactions supported by supramolecular Rh catalyst. a Rh-catalyzed hydroformylation of $\alpha, \beta$-unsaturated carboxylic acids followed by decarboxylation sequence. $\mathbf{b}$ Rh-catalyzed hydroformylation-hydrogenation of $\beta$-alkynoic acids. $\mathbf{c}$ Rh-catalyzed hydroformylation of $\alpha$-alkynoic acids followed by Michael addition and decarboxylation 


\section{Table 1 Optimization of reaction conditions ${ }^{a}$}

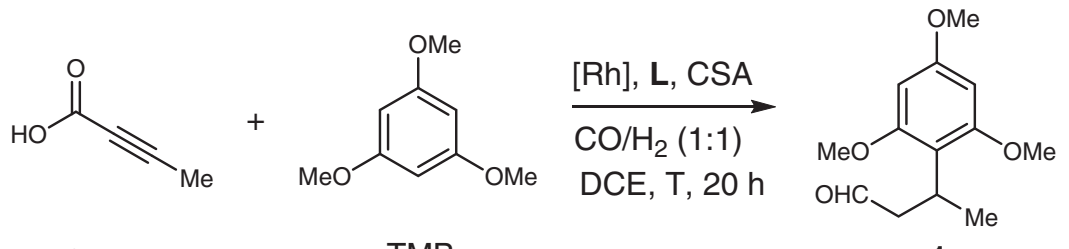

s1

TMB

1

\begin{tabular}{|c|c|c|c|c|c|}
\hline Entry & $\mathbf{L}$ & Ratio (Rh/L/CSA) & Ratio (S1/TMB) & Yield (\%) & Conv. (S1/TMB) (\%) \\
\hline $1^{b}$ & $\mathbf{L 1}$ & $1: 5: 0$ & $1: 1$ & 35 & $100 / 36$ \\
\hline $2^{b}$ & $\mathbf{L 1}$ & $1: 5: 5$ & $1: 1$ & 53 & $100 / 57$ \\
\hline 3 & $\mathbf{L 1}$ & $1: 5: 5$ & $1: 1$ & 72 & $100 / 74$ \\
\hline 4 & $\mathbf{L 1}$ & $1: 6: 6$ & $1: 1$ & 74 & $100 / 75$ \\
\hline 5 & $\mathbf{L 1}$ & $1: 6: 9$ & $1: 1$ & 37 & $100 / 70$ \\
\hline 6 & $\mathbf{L 1}$ & $1: 6: 3$ & $1: 1$ & 64 & $100 / 65$ \\
\hline 7 & $\mathbf{L 1}$ & $1: 6: 6$ & $1.5: 1$ & $90(90)$ & $95 / 95$ \\
\hline 8 & $\mathbf{L 2}$ & $1: 6: 6$ & $1.5: 1$ & 67 & $99 / 71$ \\
\hline 9 & $\mathbf{L 3}$ & $1: 6: 6$ & $1.5: 1$ & 66 & $81 / 73$ \\
\hline 10 & L4 & $1: 6: 6$ & $1.5: 1$ & 0 & $10 / 13$ \\
\hline 11 & $\mathbf{L 5}$ & $1: 6: 6$ & $1.5: 1$ & 0 & $6 / 9$ \\
\hline
\end{tabular}

$\mathrm{a}\left[\mathrm{Rh}(\mathrm{CO})_{2} \mathrm{acac}\right] / \mathrm{TMB}=1: 100,1 \mathrm{mmol}$ of $\mathrm{TMB}, \mathrm{c}(\mathbf{S 1})=0.5 \mathrm{M}, \mathrm{CO} / \mathrm{H}_{2}\left(1: 1,20\right.$ bar), $35^{\circ} \mathrm{C}$. Yield and conversion (conv.) based on TMB were determined by NMR spectroscopy using dimethylacetamide (DMAC) as the internal standard and isolated yields were shown in parentheses. ${ }^{b} 55^{\circ} \mathrm{C}$. $\mathrm{CO} / \mathrm{H}_{2}(1: 1,6$ bar). acac acetylacetonate, $\mathrm{DCE} 1,2-\mathrm{dich}$ loroethane<smiles>NC(N)=NC(=O)c1cccc(P(c2cc(F)cc(F)c2)c2cc(F)cc(F)c2)n1</smiles>

L2: $R=F$<smiles>[R]c1ccc(P(c2ccc([R])cc2)c2cccc(C(=O)N=C(N)N)n2)cc1</smiles>

L3: $\mathrm{R}=\mathrm{CF}_{3}$ L4: $R=F$<smiles>NC(N)=NC(=O)c1cccc(Pc2ccccc2)n1</smiles>

L5 products were identified. When camphorsulfonic acid (CSA) was used as the additive ${ }^{47}$, the yield of 1 was increased to $53 \%$ with a moderate conversion of $57 \%$ for TMB (Table 1, entry 2). A yield of $65 \%$ was obtained by varying the syngas pressure from 6 to 20 bar (see Supplementary Table 1). Other solvents and reaction temperatures were studied with DCE providing the most promising result at $35^{\circ} \mathrm{C}(72 \%$ yield, Table 1 , entry 3 , and see Supplementary Tables 2 and 3). Slight effects on the yield were observed when changing the ratio of Rh and L1 (Table 1, entry 3 and 4, and Supplementary Table 4). Increasing the amount of CSA from 6 to 9 mol\% (Table 1, entry 5) and decreasing it from 6 to $3 \mathrm{~mol} \%$ (Table 1 , entry 6 ) led to inferior yields (37\% and $64 \%$ yield, respectively). This indicates that the quantitative protonation of the acylguanidyl group into the acylguanidinium cation is essential for the performance of the catalyst ${ }^{47}$. Other acids were also tested (see Supplementary Table 5): $\mathrm{TsOH}$ and $\mathrm{TfOH}$ afforded lower yields, meanwhile TFA gave similar results to CSA ( $73 \%$ vs. $74 \%$ yield). Excellent yield was achieved by changing the ratio of $\mathbf{S 1}$ to TMB from 1.0 to 1.5 (90\% yield, Table 1, entry 7 ). Finally, the influence of the electronic properties of the ligand was investigated (Table 1, entries 7-11). We observed that when the $\sigma$-donor ability of the phosphine ligand was increased the catalytic activity drops to a moderate level for $\mathbf{L} 2$ and $\mathbf{L 3}$. The even more electron rich ligands $\mathbf{L} 4$ and L5 showed no product formation. This confirms that the initially used ligand $\mathbf{L} \mathbf{1}$ is superior to its analogs.

Scope of the proposed domino reaction. With the optimized reaction conditions in hand, the general scope of this catalytic protocol was examined. As shown in Table 2, when using TMB as the nucleophile, a variety of $\alpha$-alkynoic acids could be successfully transformed to the corresponding $\beta$-aryl aldehydes in good yields. The length of the alkyl chain of the substrates (from Me to $n$ $\mathrm{C}_{14} \mathrm{H}_{19}$ ) slightly affected the yields (1-11, 73-90\% yield). Bulkier secondary alkyl substituents such as $i$-Pr and Cy were well tolerated (12 and 13, 81\% and 74\% yield, respectively). Other functional groups such $\mathrm{Bn}$ and $\mathrm{CN}$ were also tested, affording the corresponding terminal aldehydes in good to excellent yields (15 and 16, 77\% and 92\% yield, respectively). Surprisingly, 3-(2,4,6trimethoxyphenyl)-propanal 17 was obtained in $51 \%$ yield by using 3- (trimethylsilyl)-2-propynoic acid S17, whereas 2propynoic acid cannot be transformed to $\mathbf{1 7}$ under the same conditions. This indicates that the TMS-protection of substrate S17 is essential to achieve the desired transformation under the reaction conditions, whereby the TMS group was cleaved in situ and product 17 was formed. 
Table 2 Substrate scope of $\alpha$-alkynoic acids with TMB ${ }^{a}$<smiles>[2H]C#CC(=O)O</smiles>

S1-S17<smiles>COc1cc(OC)cc(OC)c1</smiles>

TMB
[Rh], L1, CSA

$\mathrm{CO} / \mathrm{H}_{2}(1: 1,20$ bar $)$

DCE, $35{ }^{\circ} \mathrm{C}, 20 \mathrm{~h}$<smiles>COc1cc(OC)c(C(P)CC=O)c(OC)c1</smiles>

$1-17$<smiles>COc1cc(OC)c(C(C)CC=O)c(OC)c1</smiles>

1: $90 \%$<smiles>COc1cc(OC)c(C(CC=O)POc2ccccc2)c(OC)c1</smiles>

$5: 75 \%^{a}, 81 \%{ }^{b}$

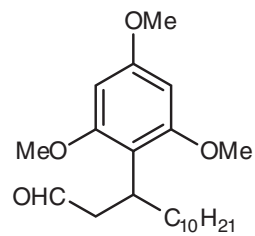

9: $78 \%$ b<smiles>COc1cc(OC)c(C(CC=O)CC2CCCCC2)c(OC)c1</smiles>

14: $77 \%$ b<smiles>CCC(CC=O)c1c(OC)cc(OC)cc1OC</smiles>

2: $82 \%$<smiles>COc1cc(OC)c(C(C=O)CO)c(OC)c1</smiles>

6: $83 \%{ }^{b}$

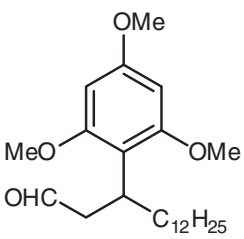

10: $83 \%$ b<smiles>COc1cc(OC)c(C(CC=O)Cc2ccccc2)c(OC)c1</smiles>

15: $77 \%$ b<smiles>CCCC(CC=O)c1c(OC)cc(OC)cc1OC</smiles>

3: $77 \%$<smiles>COc1cc(OC)c(C(CC=O)OCCO)c(OC)c1</smiles>

7: $73 \%$ b

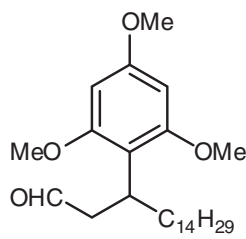

11: $74 \%$ b<smiles>COc1cc(OC)c(C(C#N)CC=O)c(OC)c1</smiles>

16: $92 \%$<smiles>CCCCC(CC=O)c1c(OC)cc(OC)cc1OC</smiles>

4: $85 \%$<smiles>COOC(CC=O)c1c(OC)cc(OC)cc1OC</smiles>

8: $83 \%^{b}$<smiles>COc1cc(OC)c(C(P)CC=O)c(OC)c1</smiles>

12: $\mathrm{R}=i-\operatorname{Pr}, 81 \%{ }^{\mathrm{b}}$

13: $R=C y, 74 \% b$<smiles>COc1cc(OC)c(CC=O)c(OC)c1</smiles>

17: $51 \%$

${ }^{\mathrm{a}}\left[\mathrm{Rh}(\mathrm{CO})_{2} \mathrm{acac}\right] / \mathbf{L 1} / \mathrm{CSA} / \mathbf{S} / \mathrm{TMB}=1: 6: 6: 150: 100,1 \mathrm{mmol}$ of TMB, DCE (3 mL). Isolated yield based on TMB. ${ }^{\mathrm{b}} \mathrm{The}$ ratio of $\mathbf{S}$ to $\mathrm{TMB}=2: 1 . \mathrm{Bn}=\mathrm{Benzyl}$

As a ubiquitous structural element, the motif of indole is frequently found in bioactive natural products and pharmaceuticals ${ }^{56,57}$. Encouraged by this fact, we decided to evaluate our supramolecular catalytic system in the presence of indole derivatives as nucleophiles (Table 3). Using modified reaction conditions (see Supplementary Table 8), 1-methylindole reacted well with $\mathbf{S 1}$, leading to the 3-(1-methyl-1H-indol-3-yl) butanal 18 in $81 \%$ yield. The chain length $\left(\mathrm{R}=n-\mathrm{C}_{14} \mathrm{H}_{19}\right)$ or bulkier substituent $(\mathrm{R}=i$-Pr) of $\alpha$-alkynoic acids slightly affected the reaction efficiency (19 and $\mathbf{2 0}, 77 \%$ and $76 \%$, respectively). Unfortunately, free indole cannot be transformed under these conditions. However, a variety of protective groups such as $\mathrm{Bn}$, PMB, and TIPS at 1-position of indole were well tolerated (21-23, $81-90 \%$ yield) overcoming this limitation by subsequent deprotection. 1-Pivaloylindole showed no activity under the same reaction conditions. Different substitution patterns at 5-position of the 1-methylindole were evaluated: the electron donating groups $\mathrm{Me}(\mathbf{2 5})$ and $\mathrm{OMe}(\mathbf{2 6})$ gave just moderate yields $(63 \%$ and $56 \%$ yield, respectively). On the other hand, electron poor substituents such as $\mathrm{F}(\mathbf{2 7})$ and $\mathrm{Br}(\mathbf{2 8})$ resulted in very good yields ( $86 \%$ and $82 \%$ yield, respectively). It should be noticed that indolyl bromide 28 might be further functionalized by transition 
Table 3 Substrate scope of indole derivatives and other nucleophilesa<smiles>C#CC(=O)O</smiles>

18: $81 \%$<smiles>CCCCCCC(C)c1cn(CC(C)C)c2ccccc12</smiles>

22: $90 \%$<smiles>COc1ccc2c(c1)c(C(C)CC=O)cn2C</smiles>

26: $56 \%$<smiles>CC(CC=O)c1c(-c2ccccc2)n(C)c2ccccc12</smiles>

30: $88 \%$<smiles>CCCCCCC(CC=O)c1cn(C)c2ccccc12</smiles>

19: $77 \%$<smiles>CC(C)Cn1cc(C(C)C)c2ccccc21</smiles>

23: $83 \%$<smiles>CC(CC=O)c1cn(C)c2ccc(F)cc12</smiles>

27: $86 \%$<smiles>COc1cc(N(C)C)ccc1C(C)CC=O</smiles>

31: $90 \%$
[Rh], L1, CSA

$\underset{\mathrm{CO} / \mathrm{H}_{2}(1: 1,30 \mathrm{bar})}{\longrightarrow}$<smiles>[B]C(N)CC=O</smiles>

18-33
$\mathrm{OHC}$<smiles>CC(C)C(CC=O)c1cn(C)c2ccccc12</smiles>

20: $76 \%$<smiles>CC(CC=O)c1cn(Cc2ccccc2)c2ccccc12</smiles>

21: $81 \%$<smiles>CCCNn1cc(C(C)CC=O)c2ccccc21</smiles>

24: NR<smiles>Cc1ccc2c(c1)c(C(C)CO)cn2C</smiles>

25: $63 \%$<smiles>CC(CC=O)c1cn(C)c2ccc(Br)cc12</smiles>

28: $82 \%$<smiles>Cc1c(C(C)CC=O)c2ccccc2n1C</smiles>

29: $48 \%$<smiles>CC(CC=O)c1ccc(N(C)C)cc1</smiles>

32: $66 \%$<smiles>COc1ccc(C(C)CC=O)c(OC)c1</smiles>

33: NR

$\mathrm{a}\left[\mathrm{Rh}(\mathrm{CO})_{2} \mathrm{acac}\right] / \mathbf{L} \mathbf{1} / \mathrm{CSA} / \mathbf{S} / \mathrm{Nu}-\mathrm{H}=1: 6: 6: 150: 100,0.5 \mathrm{mmol}$ scale of Nu-H, DCE (3 mL). Isolated yield based on used nucleophile. Piv Pivaloyl, PMB 4-methoxybenzyl, TIPS Triisopropylsilyl

metal-catalyzed cross-coupling reactions ${ }^{58}$. Substrates with substituents such as $\mathrm{Me}(\mathbf{2 9}, 48 \%$ yield $)$ and $\mathrm{Ph}(\mathbf{3 0}, \mathbf{8 8 \%}$ yield) at 2position of the indole ring were also successfully transformed. Finally, other arene nucleophiles were tested: 1-(dimethylamino)3-methoxybenzene showed high activity affording product 31 in $90 \%$ yield and when dimethylaniline was used, 32 was obtained in $66 \%$ yield. However, 1, 3-dimethoxybenzene did not react under these reaction conditions to 33 .

To further explore the potential application of our protocol in biologically active targets, a concise synthesis of a key intermediate 35a for Avitriptan ${ }^{59}$, as an attractive candidate for an antimigraine drug, was shown in Fig. 2. Under the optimal reaction conditions, benzyl protected 5-chloroindole $\mathbf{S 3 4}$ reacted well with 3-(trimethylsilyl)propynoic acid (S17), providing the desired $\beta$-aryl aldehydes 34 in 93\% $(n(\mathbf{3 4 a}): n(\mathbf{3 4 b})=1: 3)$ yields. The corresponding alcohols 35 were obtained in quantitative yields after simple reduction using $\mathrm{NaBH}_{4}$. Notably, 35b was easily transformed into $35 \mathrm{a}$ with a catalytic amount of $\mathrm{KOt} \mathrm{Bu}^{60}$.
Following the literatures known steps ${ }^{61,62}$, Avitriptan could be successfully achieved.

\section{Discussion}

To clarify the role of $\mathbf{L} \mathbf{1}$ in this domino reaction process, several control experiments were undertaken as shown in Table 4 . With a phenyl ring analog of L1, ligand L6, which may also allow for supramolecular substrate-ligand interactions, only poor yields and conversions were observed and it indicated the pyridyl ring of $\mathbf{L 1}$ is key to the catalytic activity (Table 4, entry 2). Furthermore, the combination of 2-pyridinyl-bis-[3',5'-bis(trifluoromethyl) phenyl]phosphine $\mathbf{L 7}$ and acylguanidine $\mathbf{L 8}$ resulted in no formation of the desired product (Table 4, entry 3 ). This suggests that the molecular-recognition function and the catalytic unit must be an integral part of the same molecular catalyst, to achieve the unique catalytic activity and selectivity. Using a rhodium catalyst derived from the monodentate ligand L9, only very low 
<smiles>O=CCC(P)c1cn(Cc2ccccc2)c2ccc(Cl)cc12</smiles><smiles>OCCCc1cn(Cc2ccccc2)c2ccc(Cl)cc12</smiles>

$\begin{aligned} & \text { iii, } 83 \% \longrightarrow 35 a, 99 \%, R=H \\ & 35 b, 99 \%, R=T M S\end{aligned}$<smiles>CCN(CC)CCCc1c[nH]c2ccc(CS(=O)(=O)NC)cc12</smiles>

Avitriptan

Fig. 2 Synthesis of intermediate 35a for Avitriptan. i: $\left[\mathrm{Rh}(\mathrm{CO})_{2} \mathrm{acac}\right] / \mathbf{L 1} / \mathrm{CSA} / \mathbf{S 1 7} / \mathbf{S 3 4}=1: 6: 6: 150: 100,0.5 \mathrm{mmol}$ scale of $\mathbf{S 3 4}, \mathrm{CO} / \mathrm{H}_{2}(1: 1,30 \mathrm{bar}), \mathrm{DCE}(3 \mathrm{~mL})$, $50^{\circ} \mathrm{C}, 20$ h. ii: $\mathrm{NaBH}_{4}$ (2 equiv.), $\mathrm{MeOH}, 0^{\circ} \mathrm{C}, 30$ min. iii: $\mathrm{KOtBu}(10 \mathrm{~mol} \%), 18-c r o w n-6$ (10 mol\%), DMSO: $\mathrm{H}_{2} \mathrm{O}(19: 1, \mathrm{v} / \mathrm{v}), 80^{\circ} \mathrm{C}, 5 \mathrm{~h}$. TMS $=$ trimethylsilyl

conversion $(<2 \%)$ of both substrates was observed (Table 4 , entry 4). We assumed that the substrate recognition via hydrogen bonding is crucial for our catalytic system. As expected, when $\mathrm{MeOH}$ was used as a solvent, the reactivity dramatically dropped, because the essential hydrogen bonding interactions between the catalyst and the substrate were disturbed (Table 4, entry 5). Moreover, using methyl ester S36, without the complementary acid functionality, no formation of desired $\beta$-aryl aldehyde was observed (Table 4, entry 6). When the reaction was carried out under argon instead of syngas atmosphere, the L1-derived catalyst showed basically no activity and the addition reaction of TMB to the triple bond of $\mathbf{S 1}$ was not observed (Table 4, entry 7). This suggests that the HF process is the first step of the reaction sequence rather than the addition reaction. When the reaction of S1 proceeded without addition of TMB, poor conversion $(42 \%$, Table 4, entry 8) was observed and interestingly aldehyde III (Fig. 1c) was observed in 3\% yield with poor selectivity (see Supplementary Fig. 3). This indicates that TMB could efficiently trap the intermediate generated from the HF process. Finally, when the isotopically labeled substrate $\left[1-{ }^{13} \mathrm{C}\right]-2$-nonynoic acid S37 was subjected to the reaction conditions, product 6 (without isotopic label) was observed (Table 4, entry 9). This is a clear proof that the aldehyde group was not obtained by hydrogenation of the carboxylic acid.

High-pressure in situ infrared (IR) and in situ NMR experiments were further carried out to study the reaction mechanism. As shown in Supplementary Fig. 17, the formation of characteristic signals $\left(\delta=-10.28\right.$ p.p.m., $\left.J_{\mathrm{H}-\mathrm{P}}=12.2 \mathrm{~Hz}\right)$ of Rhhydride species was observed as a triplet peak, which indicated that two L1 ligands coordinated to the Rh center. The coupling constant of Rh-P $\left(J_{\text {Rh-P }}=164.2 \mathrm{~Hz}\right.$, Supplementary Fig. 18) indicated a trigonal bipyramidal structure with an equatorial-equatorial conformation for the related $\mathrm{Rh}$ complex ${ }^{17,63,64}$. Furthermore, the formation of product could be easily followed from the high-pressure in situ IR spectroscopy (Supplementary Fig. 9). Based on the generally accepted mechanism of Rh-catalyzed $\mathrm{HF}$ in the presence of the triarylphosphine ligand and the presented results, we propose a sequential mechanism consisting of three consecutive steps: HF,
Michael addition, and decarboxylation (Fig. 3) ${ }^{65}$. The mechanism might start by the coordination of the substrate to the $\mathrm{Rh}$ complex A affording complex B, suggested by DFT calculation (see Supplementary Fig. 19), where the substrate is activated via recognition and preorientation to the $\mathrm{Rh}$ center. Due to this interaction, an $\alpha$-selective $\mathrm{HF}$ could take place giving rise to intermediate $\mathbf{C}^{41}$. Then, intermediate $\mathbf{D}$ could be released regenerating the initial $\mathrm{Rh}$ complex $\mathbf{A}$. Intermediate $\mathbf{D}$ might further proceed via Michael addition of an arene nucleophile to intermediate $\mathbf{E}$, followed by the decarboxylation process affording the final product.

The order of this reaction pathway was further confirmed by the control experiments shown in Fig. 4. The $\alpha, \beta$-unsaturated aldehyde (38) and TMB were subjected to the optimized reaction conditions with (i) and without (ii) the catalyst. In none of these cases, product formation was observed. This provided a solid support that the Michael addition occurs before the decarboxylation step.

In conclusion, we have successfully developed a domino process from easily accessible $\alpha$-alkynoic acids, which yields valuable $\beta$-aryl aldehydes with high molecular complexity tolerating a variety of functional groups. Furthermore, the synthesis of a key intermediate of Avitriptan using this protocol was accomplished. Based on our study of the reaction mechanism, this domino reaction is triggered by the $\mathrm{Rh}$-catalyzed $\mathrm{HF}$ of $\alpha$-alkynoic acids promoted by hydrogen-bonding interaction between the ligand and the substrate. Consecutive Michael addition of arenes as nucleophiles followed by decarboxylation of the carboxyl function leads to the $\beta$-aryl aldehyde products. It should be noticed that the carboxyl function plays a crucial role as a transient and traceless directing group for the introduction of the aldehyde function. This study also highlights the unique advantages of the substrate recognition-directed catalysis in combination with domino reactions. Investigations for an asymmetric version of this protocol are currently being undertaken in our lab.

\section{Methods}

General procedure $\boldsymbol{D}$ for the catalysis reaction. To a flame dried glass liner (Supplementary Fig. 2a) containing a magnetic stirring bar, $\left[\mathrm{Rh}(\mathrm{CO})_{2} \mathrm{acac}\right]$, ligand 


\section{Table 4 Control experiments ${ }^{a}$}<smiles>O=C(O)C#C[18O]</smiles><smiles>COc1cc(OC)cc(OC)c1</smiles>

TMB

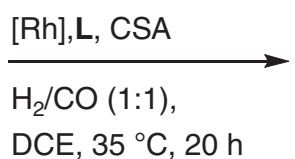

DCE, $35^{\circ} \mathrm{C}, 20 \mathrm{~h}$<smiles>CCC(CC=O)c1c(OC)cc(OC)cc1OC</smiles>

Product

\begin{tabular}{|c|c|c|c|c|}
\hline Entry & Ligand & Substrate (S) & Yield (\%) & Conv. (S/TMB) (\%) \\
\hline $\begin{array}{l}1 \\
2 \\
3 \\
4 \\
5^{b} \\
6 \\
7^{c} \\
8^{d} \\
9^{e}\end{array}$ & $\begin{array}{l}\text { L1 } \\
\text { L6 } \\
\text { L7/L8 } \\
\text { L9 } \\
\text { L1 } \\
\text { L1 } \\
\text { L1 } \\
\text { L1 } \\
\text { L1 }\end{array}$ & $\begin{array}{l}\text { S1 } \\
\text { S1 } \\
\text { S1 } \\
\text { S1 } \\
\text { S1 } \\
\text { S36 } \\
\text { S1 } \\
\text { S1 } \\
\text { S37 }\end{array}$ & $\begin{array}{l}90(90) \\
16 \\
0 \\
0 \\
<4 \\
0 \\
0 \\
- \\
78\end{array}$ & $\begin{array}{l}95 / 95 \\
36 / 36 \\
7 / 9 \\
2 / 2 \\
15 / 18 \\
60 / 1 \\
6 / 2 \\
42 /- \\
81 / 89\end{array}$ \\
\hline
\end{tabular}

a1 mmol scale of $\mathrm{TMB},\left[\mathrm{Rh}(\mathrm{CO})_{2}\right.$ acac $] / \mathbf{L} 1 / \mathrm{CSA} / \mathbf{S} / \mathrm{TMB}=1: 6: 6: 150: 100, \mathrm{DCE}(3 \mathrm{~mL})$. Yield and conversion were determined by NMR spectroscopy using DMAc as the internal standard and isolated yields based on TMB were shown within parentheses. ${ }^{b} \mathrm{MeOH}$ was used instead of $\mathrm{DCE}$. ${ }^{\mathrm{c}}$ Argon $(1 \mathrm{bar})$ was used instead of syngas. ${ }^{\mathrm{d}} \mathrm{Without} \mathrm{TMB}$. ${ }^{\mathrm{E}}\left[\mathrm{Rh}(\mathrm{CO}){ }_{2}\right.$ acac $] / \mathbf{L 1} / \mathrm{CSA} / \mathbf{S 3 7} / \mathrm{TMB}=1: 6: 6: 200: 100$<smiles>CC#CC(=O)O</smiles>

S1<smiles>CC#CC(=O)OC</smiles>

S36

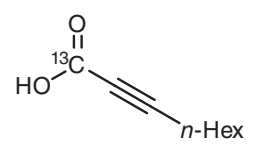

S37<smiles>NC(N)=NC(=O)c1cccc(P(c2cc(C(F)(F)F)cc(C(F)(F)F)c2)c2cc(C(F)(F)F)cc(C(F)(F)F)c2)c1</smiles>

L6<smiles>FC(F)(F)c1cc(P(c2cc(C(F)(F)F)cc(C(F)(F)F)c2)c2ccccn2)cc(C(F)(F)F)c1</smiles>

L7<smiles>NC(N)=NC(=O)c1ccccn1</smiles>

L8

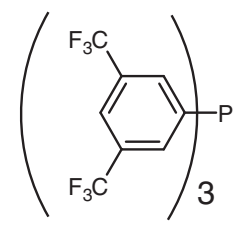

L9

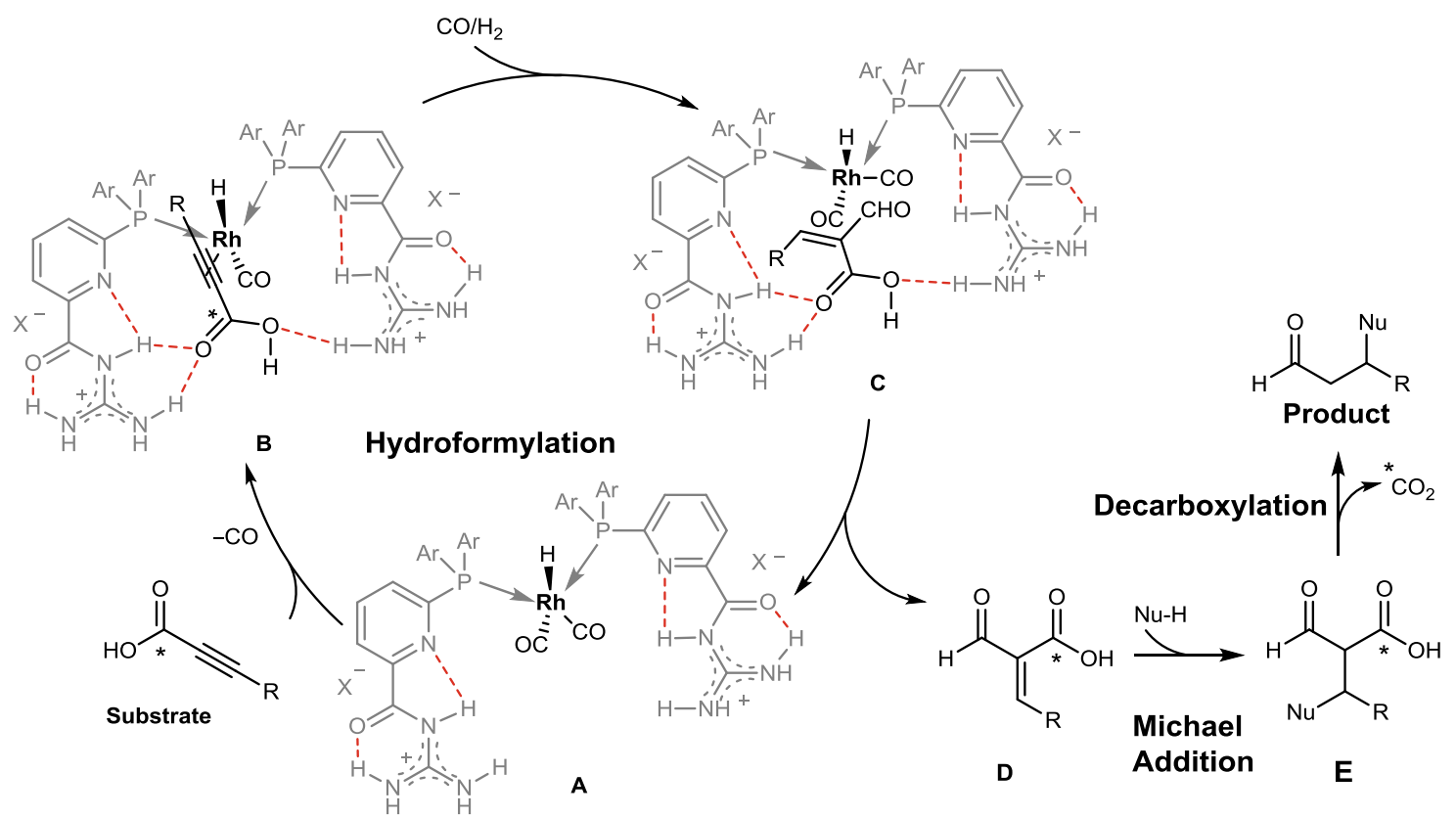

Fig. 3 Proposed reaction mechanism. It includes Rh-catalyzed hydroformylation of $\alpha$-alkynoic acids, Michael addition of arene nucleophiles, and decarboxylation 
<smiles>C/C=C/C=O</smiles><smiles>COc1cc(OC)cc(OC)c1</smiles>
38 TMB i or ii

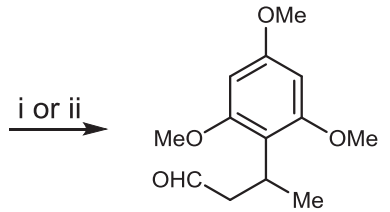

no reaction

Fig. 4 Controlled experiments of the Michael addition. i: [Rh(CO) $\left.{ }_{2} \mathrm{acac}\right] /$ L1/CSA/38/TMB = 1:6:6:150:100, $0.5 \mathrm{mmol}$ scale of TMB, DCE $(1.5 \mathrm{~mL})$, $35^{\circ} \mathrm{C}, 24 \mathrm{~h}$, Argon. ii: $n(\mathbf{3 8}): n(T M B)=1.5: 1,1 \mathrm{mmol}$ scale of TMB, DCE $(2 \mathrm{~mL}), 35^{\circ} \mathrm{C}, 24 \mathrm{~h}$, Argon

L1, 1,3,5-trimethoxybenzene (TMB) (or other nucleophiles), and CSA were added subsequently. The glass liner was sealed by an aluminum crimp cap with silicon septum (Supplementary Fig. 2a) and argon was purged for 5 min via syringes (Supplementary Fig. 2b). DCE was added followed by the liquid substrate (if the substrate was a solid, it was added before purging argon) via a syringe under argon atmosphere. The reaction mixture was stirred for $10 \mathrm{~min}$ (a clear reaction solution was obtained; Supplementary Fig. 2c). The glass liner was transferred into the Premex stainless steel autoclave Medimex $(100 \mathrm{~mL})$ under argon atmosphere quickly. The autoclave was purged three times with $5 \mathrm{bar}$ of synthesis gas $\left(\mathrm{CO} / \mathrm{H}_{2}\right.$, 1:1) and was pressurized to $20 \mathrm{bar}$ (or $30 \mathrm{bar}$ ). Then, it was conducted at $35^{\circ} \mathrm{C}$ (or $50^{\circ} \mathrm{C}$ ) for $20 \mathrm{~h}$. Afterwards, the autoclave was cooled down to room temperature and depressurized. Then, 0.5 equiv. of dimethylacetamide (DMAc, $43.6 \mathrm{mg}$ ) was added as the internal standard into the crude reaction mixture. Samples were analyzed by NMR analysis after the evaporation of solvent. The corresponding aldehydes were purified by flash chromatography to afford analytically pure products.

Caution: All operations involving carbon monoxide must be carried out in a well-ventilated fume-hood. Use of a gas-leak detector for carbon monoxide is highly recommended.

\section{Data availability}

For experimental details and procedures, spectra for all unknown compounds and details from DFT calculation, see Supplementary Files. All data underlying the findings of this study are available from the corresponding author upon reasonable request.

Received: 11 May 2019; Accepted: 24 September 2019; Published online: 25 October 2019

\section{References}

1. Trost, B. M. Atom economy-a challenge for organic synthesis: Homogeneous catalysis leads the way. Angew. Chem. Int. Ed. 34, 259-281 (1995).

2. Raynal, M., Ballester, P., Vidal-Ferran, A. \& van Leeuwen, P. W. Supramolecular catalysis. Part 1: non-covalent interactions as a tool for building and modifying homogeneous catalysts. Chem. Soc. Rev. $\mathbf{4 3}$, 1660-1733 (2014).

3. Raynal, M., Ballester, P., Vidal-Ferran, A. \& van Leeuwen, P. W. Supramolecular catalysis. Part 2: artificial enzyme mimics. Chem. Soc. Rev. 43, 1734-1787 (2014).

4. Breit, B. Supramolecular approaches to generate libraries of chelating bidentate ligands for homogeneous catalysis. Angew. Chem. Int. Ed. 44, 6816-6825 (2005).

5. Meeuwissen, J. \& Reek, J. N. Supramolecular catalysis beyond enzyme mimics. Nat. Chem. 2, 615-621 (2010).

6. Carboni, S., Gennari, C., Pignataro, L. \& Piarulli, U. Supramolecular ligand ligand and ligand-substrate interactions for highly selective transition metal catalysis. Dalton Trans. 40, 4355-4373 (2011).

7. Dydio, P. \& Reek, J. N. H. Supramolecular control of selectivity in transitionmetal catalysis through substrate preorganization. Chem. Sci. 5, 2135-2145 (2014).

8. Davis, H. J. \& Phipps, R. J. Harnessing non-covalent interactions to exert control over regioselectivity and site-selectivity in catalytic reactions. Chem. Sci. 8, 864-877 (2017).

9. Mote, N. R. \& Chikkali, S. H. Hydrogen-bonding-assisted supramolecular metal catalysis. Chem. Asian J. 13, 3623-3646 (2018).

10. Nurttila, S. S., Linnebank, P. R., Krachko, T. \& Reek, J. N. H. Supramolecular approaches to control activity and selectivity in hydroformylation catalysis. ACS Catal. 8, 3469-3488 (2018).

11. Das, S., Incarvito, C. D., Crabtree, R. H. \& Brudvig, G. W. Molecular recognition in the selective oxygenation of saturated $\mathrm{C}-\mathrm{H}$ bonds by a dimanganese catalyst. Science 312, 1941-1943 (2006).

12. Dydio, P., Dzik, W. I., Lutz, M., de Bruin, B. \& Reek, J. N. Remote supramolecular control of catalyst selectivity in the hydroformylation of alkenes. Angew. Chem. Int. Ed. 50, 396-400 (2011).

13. Dydio, P., Rubay, C., Gadzikwa, T., Lutz, M. \& Reek, J. N. "Cofactor"-controlled enantioselective catalysis. J. Am. Chem. Soc. 133, 17176-17179 (2011).

14. Dydio, P., Detz, R. J. \& Reek, J. N. Precise supramolecular control of selectivity in the Rh-catalyzed hydroformylation of terminal and internal alkenes. J. Am. Chem. Soc. 135, 10817-10828 (2013).

15. Dydio, P., Ploeger, M. \& Reek, J. N. H. Selective isomerization-hydroformylation sequence: A strategy to valuable $\alpha$-methyl-branched aldehydes from terminal olefins. ACS Catal. 3, 2939-2942 (2013).

16. Dydio, P. \& Reek, J. N. H. Supramolecular control of selectivity in hydroformylation of vinyl arenes: easy access to valuable $\beta$-aldehyde intermediates. Angew. Chem. Int. Ed. 52, 3878-3882 (2013).

17. Dydio, P., Detz, R. J., de Bruin, B. \& Reek, J. N. Beyond classical reactivity patterns: hydroformylation of vinyl and allyl arenes to valuable $\beta$ - and $\gamma$ aldehyde intermediates using supramolecular catalysis. J. Am. Chem. Soc. 136, 8418-8429 (2014)

18. Dydio, P. \& Reek, J. N. Scalable and chromatography-free synthesis of 2-(2formylalkyl)arenecarboxylic acid derivatives through the supramolecularly controlled hydroformylation of vinylarene-2-carboxylic acids. Nat. Protoc. 9, 1183-1191 (2014).

19. Théveau, L. et al. Cofactor-controlled chirality of tropoisomeric ligand. Organometallics 35, 1956-1963 (2016).

20. Fackler, P., Berthold, C., Voss, F. \& Bach, T. Hydrogen-bond-mediated enantio- and regioselectivity in a Ru-catalyzed epoxidation reaction. J. Am. Chem. Soc. 132, 15911-15913 (2010).

21. Voss, F., Herdtweck, E. \& Bach, T. Hydrogen bond induced enantioselectivity in $\mathrm{mn}$ (salen)-catalysed sulfoxidaton reactions. Chem. Commun. 47, 2137-2139 (2011)

22. Fackler, P., Huber, S. M. \& Bach, T. Enantio- and regioselective epoxidation of olefinic double bonds in quinolones, pyridones, and amides catalyzed by a Ruthenium porphyrin catalyst with a hydrogen bonding site. J. Am. Chem. Soc. 134, 12869-12878 (2012).

23. Hoke, T., Herdtweck, E. \& Bach, T. Hydrogen-bond mediated regio- and enantioselectivity in a C-H amination reaction catalysed by a supramolecular $\mathrm{Rh}$ (ii) complex. Chem. Commun. 49, 8009-8011 (2013).

24. Zhong, F. \& Bach, T. Enantioselective construction of 2,3-dihydrofuro[2,3-b] quinolines through supramolecular hydrogen bonding interactions. Chem. Eur. J. 20, 13522-13526 (2014).

25. Frost, J. R., Huber, S. M., Breitenlechner, S., Bannwarth, C. \& Bach, T. Enantiotopos-selective $\mathrm{C}-\mathrm{H}$ oxygenation catalyzed by a supramolecular Ruthenium complex. Angew. Chem. Int. Ed. 54, 691-695 (2015).

26. Zhong, F., Pothig, A. \& Bach, T. Synergistic stereocontrol in the enantioselective Ruthenium-catalyzed sulfoxidation of spirodithiolaneindolones. Chem. Eur. J. 21, 10310-10313 (2015).

27. Burg, F., Gicquel, M., Breitenlechner, S., Pothig, A. \& Bach, T. Site- and enantioselective $\mathrm{C}-\mathrm{H}$ oxygenation catalyzed by a chiral Manganese porphyrin complex with a remote binding site. Angew. Chem. Int. Ed. 57, 2953-2957 (2018).

28. Zhao, Q., Li, S., Huang, K., Wang, R. \& Zhang, X. A novel chiral bisphosphine-thiourea ligand for asymmetric hydrogenation of $\beta, \beta$ disubstituted nitroalkenes. Org. Lett. 15, 4014-4017 (2013).

29. Zhao, Q. et al. Rhodium-catalyzed asymmetric hydrogenation of unprotected $\mathrm{NH}$ imines assisted by a thiourea. Angew. Chem. Int. Ed. 53, 8467-8470 (2014).

30. Han, Z. et al. Highly enantioselective synthesis of chiral succinimides via $\mathrm{Rh} /$ bisphosphine-thiourea-catalyzed asymmetric hydrogenation. ACS Catal. 6 , 6214-6218 (2016).

31. Li, P., Hu, X., Dong, X.-Q. \& Zhang, X. Rhodium/bisphosphine-thioureacatalyzed enantioselective hydrogenation of $\alpha, \beta$-unsaturated $N$-acylpyrazoles. Chem. Commun. 52, 11677-11680 (2016).

32. Li, P. et al. Synthesis of chiral $\beta$-amino nitroalkanes via Rhodium-catalyzed asymmetric hydrogenation. Org. Lett. 18, 40-43 (2016).

33. Wen, J., Jiang, J. \& Zhang, X. Rhodium-catalyzed asymmetric hydrogenation of $\alpha, \beta$-unsaturated carbonyl compounds via thiourea hydrogen bonding. Org. Lett. 18, 4451-4453 (2016).

34. Wen, J., Tan, R., Liu, S., Zhao, Q. \& Zhan, X. Strong brønsted acid promoted asymmetric hydrogenation of isoquinolines and quinolines catalyzed by a $\mathrm{Rh}-$ thiourea chiral phosphine complex via anion binding. Chem. Sci. 7, 3047-3051 (2016).

35. Han, Z., Wang, R., Gu, G., Dong, X.-Q. \& Zhang, X. Asymmetric hydrogenation of maleic anhydrides catalyzed by $\mathrm{Rh} /$ bisphosphine-thiourea: Efficient construction of chiral succinic anhydride. Chem. Commun. 53, $4226-4229$ (2017). 
36. Li, P., Huang, Y., Hu, X., Dong, X. Q. \& Zhang, X. Access to chiral sevenmember cyclic amines via Rh-catalyzed asymmetric hydrogenation. Org. Lett. 19, 3855-3858 (2017).

37. Zhang, T., Jiang, J., Yao, L., Geng, H. \& Zhang, X. Highly efficient synthesis of chiral aromatic ketones via $\mathrm{Rh}$-catalyzed asymmetric hydrogenation of $\beta, \beta$ -disubstituted enones. Chem. Commun. 53, 9258-9261 (2017).

38. Zhang, Z., Han, Z., Gu, G., Dong, X.-Q. \& Zhang, X. Enantioselective synthesis of chiral 3-substituted-3-silylpropionic esters via Rhodium/ bisphosphine-thiourea-catalyzed asymmetric hydrogenation. Adv. Synth. Catal. 359, 2585-2589 (2017).

39. $\mathrm{Li}, \mathrm{X}$. et al. Rhodium-catalyzed asymmetric hydrogenation of $\beta$ cyanocinnamic esters with the assistance of a single hydrogen bond in a precise position. Chem. Sci. 9, 1919-1924 (2018).

40. Lang, Q., Gu, G., Cheng, Y., Yin, Q. \& Zhang, X. Highly enantioselective synthesis of chiral $\gamma$-lactams by Rh-catalyzed asymmetric hydrogenation. ACS Catal. 8, 4824-4828 (2018).

41. Smejkal, T. \& Breit, B. A supramolecular catalyst for regioselective hydroformylation of unsaturated carboxylic acids. Angew. Chem. Int. Ed. 47, 311-315 (2008).

42. Smejkal, T. \& Breit, B. A supramolecular catalyst for the decarboxylative hydroformylation of $\alpha, \beta$-unsaturated carboxylic acids. Angew. Chem. Int. Ed. 47, 3946-3949 (2008).

43. Smejkal, T., Gribkov, D., Geier, J., Keller, M. \& Breit, B. Transition-state stabilization by a secondary substrate-ligand interaction: a new design principle for highly efficient transition-metal catalysis. Chem. Eur. J. 16, 2470-2478 (2010).

44. Diab, L., Smejkal, T., Geier, J. \& Breit, B. Supramolecular catalyst for aldehyde hydrogenation and tandem hydroformylation-hydrogenation. Angew. Chem. Int. Ed. 48, 8022-8026 (2009).

45. Fuchs, D., Rousseau, G., Diab, L., Gellrich, U. \& Breit, B. Tandem Rhodiumcatalyzed hydroformylation-hydrogenation of alkenes by employing a cooperative ligand system. Angew. Chem. Int. Ed. 51, 2178-2182 (2012).

46. Diab, L., Gellrich, U. \& Breit, B. Tandem decarboxylative hydroformylationhydrogenation reaction of $\alpha, \beta$-unsaturated carboxylic acids toward aliphatic alcohols under mild conditions employing a supramolecular catalyst system. Chem. Commun. 49, 9737-9739 (2013).

47. Fang, W. \& Breit, B. Tandem regioselective hydroformylation-hydrogenation of internal alkynes using a supramolecular catalyst. Angew. Chem. Int. Ed. 57, 14817-14821 (2018).

48. Tietze, L. F. Domino reactions in organic synthesis. Chem. Rev. 96, 115-136 (1996).

49. Nicolaou, K. C. \& Chen, J. S. The art of total synthesis through cascade reactions. Chem. Soc. Rev. 38, 2993-3009 (2009).

50. Poulin, J., Grise-Bard, C. M. \& Barriault, L. Pericyclic domino reactions: Concise approaches to natural carbocyclic frameworks. Chem. Soc. Rev. 38, 3092-3101 (2009).

51. Volla, C. M., Atodiresei, I. \& Rueping, M. Catalytic C-C bond-forming multicomponent cascade or domino reactions: Pushing the boundaries of complexity in asymmetric organocatalysis. Chem. Rev. 114, 2390-2431 (2014).

52. Mayer, S. F., Kroutil, W. \& Faber, K. Enzyme-initiated domino (cascade) reactions. Chem. Soc. Rev. 30, 332-339 (2001).

53. Abillard, O. \& Breit, B. Domino hydroformylation/enantioselective cross-aldol addition. Adv. Synth. Catal. 349, 1891-1895 (2007).

54. Duerfeldt, A. S., Brandt, G. E. L. \& Blagg, B. S. J. Design, synthesis, and biological evaluation of conformationally constrained cis-amide Hsp90 inhibitors. Org. Lett. 11, 2353-2356 (2009).

55. Payne, D. T., Zhao, Y. \& Fossey, J. S. Ethylenation of aldehydes to 3-propanal, propanol and propanoic acid derivatives. Sci. Rep. 7, 1720 (2017).

56. Cacchi, S. \& Fabrizi, G. Synthesis and functionalization of indoles through Palladium-catalyzed reactions. Chem. Rev. 105, 2873-2920 (2005).

57. Cacchi, S. \& Fabrizi, G. Update 1 of: synthesis and functionalization of indoles through Palladium-catalyzed reactions. Chem. Rev. 111, PR215-PR283 (2011).

58. Biffis, A., Centomo, P., Del Zotto, A. \& Zecca, M. Pd metal catalysts for crosscouplings and related reactions in the 21st century: a critical review. Chem. Rev. 118, 2249-2295 (2018).
59. Saxena, P. R. et al. Effects of avitriptan, a new 5-HT $\mathrm{T}_{1 \mathrm{~B} / 1 \mathrm{D}}$ receptor agonist, in experimental models predictive of antimigraine activity and coronary sideeffect potential. Naunyn Schmiedeberg. Arch. Pharmacol. 355, 295-302 (1997).

60. Hudrlik, P. F., Holmes, P. E. \& Hudrlik, A. M. Protiodesilylation reactions of $\beta$-and $\gamma$-hydroxysilanes: deuterium labeling and silicon-directed epoxide openings. Tetrahedron Lett. 29, 6395-6398 (1988).

61. Brodfuehrer, P. R. et al. An efficient fischer indole synthesis of avitriptan, a potent 5-HT $1 \mathrm{D}$ receptor agonist. J. Org. Chem. 62, 9192-9202 (1997).

62. Zheng, B., Li, M., Gao, G., He, Y. \& Walsh, P. J. Palladium-catalyzed aarylation of methyl sulfonamides with aryl chlorides. Adv. Synth. Catal. 358, 2156-2162 (2016)

63. Diebolt, O., Tricas, H., Freixa, Z. \& van Leeuwen, P. W. N. M. Strong $\pi$-acceptor ligands in rhodium-catalyzed hydroformylation of ethene and 1octene: operando catalysis. ACS Catal. 3, 128-137 (2013).

64. van Leeuwen P. W. N. M. \& Claver C. Rhodium Catalyzed Hydroformylation (Kluwer Academic Publisher, 2016).

65. Sträter, N., Lipscomb, W. N., Klabunde, T. \& Krebs, B. Two-metal ion catalysis in enzymatic acyl and phosphoryl-transfer reactions. Angew. Chem. Int. Ed. 35, 2024-2055 (1996).

\section{Acknowledgements}

We thank the Alexander von Humboldt Foundation (W.F.) for a postdoctoral fellowship. We thank Dr. Manfred Keller for invaluable assistance with NMR spectroscopy.

\section{Author contributions}

W.F. conceived the idea. W.F. performed the synthesis, experiments, and characterizations. F.B. performed experiments and NMR tests. Y.D. performed some NMR tests. W.F. and F.B. discussed the results and commented on the manuscript. W.F. wrote the manuscript. B.B. revised the manuscript and supervised the work

\section{Competing interests}

The authors declare no competing interests.

\section{Additional information}

Supplementary information is available for this paper at https://doi.org/10.1038/s41467 019-12770-w.

Correspondence and requests for materials should be addressed to B.B.

Peer review information Nature Communications thanks the anonymous reviewer(s) for their contribution to the peer review of this work.

Reprints and permission information is available at http://www.nature.com/reprints

Publisher's note Springer Nature remains neutral with regard to jurisdictional claims in published maps and institutional affiliations.

Open Access This article is licensed under a Creative Commons Attribution 4.0 International License, which permits use, sharing, adaptation, distribution and reproduction in any medium or format, as long as you give appropriate credit to the original author(s) and the source, provide a link to the Creative Commons license, and indicate if changes were made. The images or other third party material in this article are included in the article's Creative Commons license, unless indicated otherwise in a credit line to the material. If material is not included in the article's Creative Commons license and your intended use is not permitted by statutory regulation or exceeds the permitted use, you will need to obtain permission directly from the copyright holder. To view a copy of this license, visit http://creativecommons.org/ licenses/by/4.0/.

(c) The Author(s) 2019 